原 著

\title{
膵癌の病理学的ならび臨床的研究 \\ Pathological and Clinical Study of Pancreatic Carcinoma
}

炭田正孝*

MASATAKA SUMIDA, M.D.

1972年から1982年 6 月までの10年 6 か月間飞, 順天堂大学医学部消化器内科で診断した腄癌 122 例を検討した．また剖検63例, 切除21例, 計84例を用いて病理学的研究も行った. 腫湟の大ささは 最小 $1.2 \times 1.0 \mathrm{~cm}$ から最大 $9 \times 11 \mathrm{~cm}$ までであった. 血管造影所見と病理所見を対比検討して, 膵癌に 特異的な血管造影所見, 動脈の encasement と閉塞の成因を組織学的に明らかにした. 血管造影飞 よる癌の大きさの診断, 門脈浸潤, 膵被膜浸潤の診断能を検討した. 超音波検査 (US), コンピ ュータ一断層撮影 ( C T ), 内視鏡的䐙胆管造影 ( E R C P ), 血管造影の膵癌診断能を調べた. 切 除例, 非切除例共飞各種検查法の診断能は $86 \%$ から $100 \%$, 差はなかった. 各種検査法の膵癌診 断の信頼度を検討した。U S は粠疾患のスクリーニング検查法として最適であるが，その所見が陽 性にでた時の信頼度は低いので，CTかER C Pを行わなくてはならない。大きな膵癌はU S と C Tだけで診断できる. $3 \mathrm{~cm}$ 以下の膵癌の診断ては E R C P, 血管造影飞よる組み合わせ診断が必 要である. 血管造影は膵疾患の良悪性の鑑別診断, 小膵癌の確定診断, 特よび切除可否の決定には 不可欠な検查法である.

索引用語 : 膡癌, 病理, 血管造影, 総合診断.

Key words : Pancreatic carcinoma, Pathology, Angiography, Algorithmic approach.

\section{はじめに}

膵癌は年々增加の傾向にあるが1)，午の $70 \sim 80$ \%は切除不能な進行膵癌で, 予後は不良であ る2 ～脺内に限局する小さな癌を診断し切除す れば, 予後は改善する(5) 7). 小膵癌が診断, 切除 されることはすれで, その臨床的, ならびに, 病 理学的研究は少ない(8) 15).

近年, 超音波検查 (ultrasonography $=\mathrm{US}$ ), コソピューター断層撮影 (computer tomography

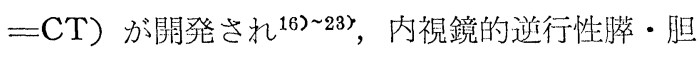

* 順天堂大学医学部内科学教室 - 消化器 Department of Gastroenterology, Internal Medicine, Juntendo University School of Medicine.

(Apr. 7, 1983 受付)
管造影 (endoscopic retrograde cholangiopancreatography $=\mathrm{ERCP})$ ，血管造影飞US，C Tを 組又合わせて彰断が行われるようになった ${ }^{24) ~ 299 . ~}$ これらの検查法を能率よく組又合わせ，膵内に限 局する小膵癌を䛦断することが現在の課題であ る.この中で血管造影は小膵癌の確定部断，良悪 性の鑑別, 切除可否の決定に不可欠な検査法であ る10)11)24)28)30) 34).

膵癌の血管造影所見と病理組織所見を対比し て，血管造影所見の成り立ちと診断能を榆討し た. 各種検査法の薠癌診断能を調べ, 検查の施行 順序について考察した.

\section{研究方法, ならびに研究材料}

\section{A. 研究方法}


1）膵癌の血管造影所見を明らかにするため に, 膵癌剖検 14 例, 切除13例で動脈の roentgenogram を作製し，血管造影所見を分析して，肉眼 所見と対比した。

2 ）血管造影所見の成因を，組織連続標本を作 製して病理組織学的に研究した.

3 ）膵を全割し, 癌の肉眼的大きさと血管造影 所見を比較して，癌の大きさの診断を検討した.

4 ) 門脈浸潤, 膵被膜浸潤の診断を切除例, 膵 内限局型癌で調べ，血管造影の診断能を検討し た。

5 ) 切除不能な膵癌の進展様式を病理解剖学的 飞分析し, 各種検査法の進展様式の䛦断能を検討 した。

6 ) 膵癌を病理組織学的に調べた結果, 能率の よい膵癌の診断大系について考察した.

\section{B. 研究材料}

1972年 1 月から1982年 6 月までの 10 年 6 カ月間 に, 順天堂大学消化器内科で診断した原発性膵癌 剖検63例, 切除21例, 姑息手術17例, 臨床 21 例, 計122例を用いた。癌の局在は頭部78例，体尾部36 例, 全体 8 例であった.

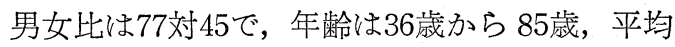
62歳であった.

各種検查法の施行件数は，U S 4 年 8 カ月間 に 5,505 例， $\mathrm{C} \mathrm{T}$ は 5 年 6 カ月間に 768 例, $\mathrm{E} \mathrm{R} \mathrm{C}$ $\mathrm{P}$ は 10 年 6 力月間に 3,209 例，血管造影は 10 年 6 カ月間に 2,636 例施行した. 膵癌は U S , C Tで 28例, E R C P で 95例, 血管造影で 112 例診断し た. 最小病変は $1.2 \times 1.0 \mathrm{~cm}$, 最大病変は $9 \times 11 \mathrm{~cm}$ であった。

\section{研究成績}

\section{A. 病理学的事項 ${ }^{16), 36) ~ 42) ~}$}

\section{1. 肉眼所見}

膵癌は縮小しながら浸潤・增殖していく型と, 膨脹性に発育浸潤していく型の 2 つ分類でき る. 割面の性状は，前者は線維性基質量が多く， 後者は少ない癌が多い。

肉眼所見の明らかな膵癌74例 中線維性基質量が

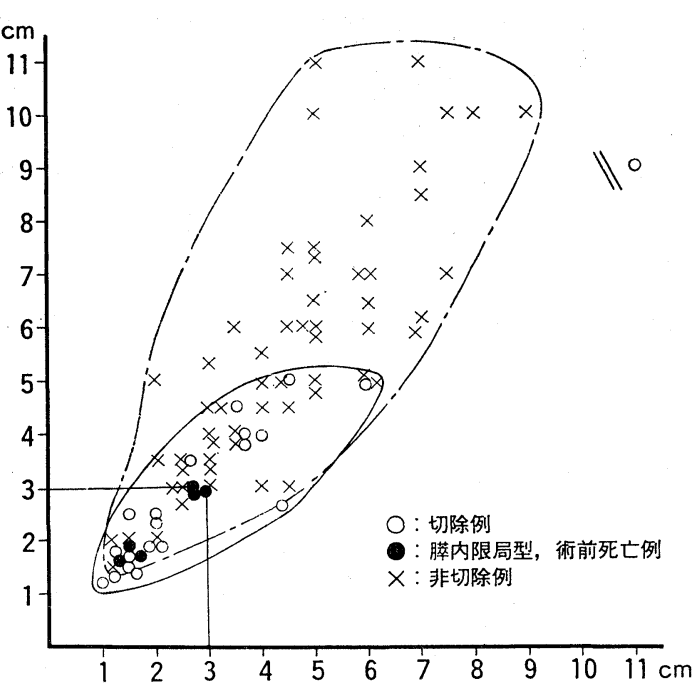

表 1 剖検63例, 切除21例の膵癌の大ささと その分布

\begin{tabular}{|c|c|c|c|c|c|c|}
\hline & \multirow{2}{*}{$\begin{array}{c}\text { 乳頭状 } \\
\text { 腺管腺癌 } \\
(n=9)\end{array}$} & \multicolumn{3}{|c|}{ 腺 管腺 癌 $(n=53)$} & \multirow{2}{*}{$\begin{array}{l}\text { (腺) 扁平 } \\
\text { 上皮癌 } \\
(n=7)\end{array}$} & \multirow{2}{*}{$\begin{array}{c}\text { 未分化癌 } \\
(n=2)\end{array}$} \\
\hline & & \begin{tabular}{|l|} 
高分化型 \\
$(n=24)$
\end{tabular} & $\begin{array}{l}\text { 中分化型 } \\
(\mathrm{n}=22)\end{array}$ & $\begin{array}{l}\text { 低分化型 } \\
(n=7)\end{array}$ & & \\
\hline $\begin{array}{r}\text { 線維基質量 } \uparrow \\
(n=37)\end{array}$ & $5(4)$ & $19(6)$ & 8 & 2(2) & 0 & 0 \\
\hline $\begin{array}{r}\text { 線維基質量 } \\
(n=37)\end{array}$ & 3 & 4 & $10(1)$ & $6(2)$ & 7 & 2 \\
\hline
\end{tabular}

( ) : 切除例

表 2 膵癌の肉眼所見と組織型

多い癌は37例, 少ない癌は37例であった。切除例 では前者は12例，後者は 3 例であった. 大きさ別 でみると，3 cm以下の癌18例中16例 89\%は基質量 が多く, $6 \mathrm{~cm}$ 以上の癌28例中 20 例 $71 \%$ は基質量の 少ない癌であった.

剖検63例, 切除21例, 計84例で癌の大きさを 調ベると， $5 \mathrm{~cm}$ 以上の癌は切除不能であった（表 $1)$.

体尾部・鉤部に発生した癌は，2 cm をこえれば 進行癌の形態をとる. 基質量の多い癌の中には, 浸潤・增殖する過程で主腫瘍部が 縮小する例があ る.

2 . 組織所見

組織所見の明らかな膵癌は71例で, 全例導管上 皮由来の癌であった。 
組織型別では, 腺管腺癌が 51 例でもっとも多 $<$, 乳頭状腺管腺癌 9 例, (腺) 扁平上皮癌 7 例; 末分化癌 2 例がこれについだ.

肉眼所見との関係は，線維性基質量の多い癌は 乳頭状腺管腺癌, 高分化型腺管腺癌が多く, 基質 量の少ない癌は分化度の低い腺管腺癌が多かっ た. (腺) 扁平上皮癌，未分化癌は基質量が少ない 癌だけに認められた（表 2)。

\section{3 . 進展様式}

剖検・切除例のうち癌の進展様式が検索でさた 症例は頭部癌50例, 体尾部癌27例, 全体癌 6 例, 計83例であった.このうち切除例は頭部癌 18例, 体尾部癌 3 例, 計21例であった。

胆管浸潤は頭部癌 46 例 $92 \%$ ，体 尾部癌10 例 37 $\%$, 全体癌 6 例 $100 \%$ あったた。切除例では頭部 癌16例 $89 \%$ であった。

十二指腸浸潤は頭部癌 33 例 $66 \%$ ，体尾部癌 8 例 $30 \%$ ，全体癌 4 例 $67 \%$ であった.

癌の浸潤による主膵管の狭窄，閉塞は74例中70 例95\%例にみられ，主膵管に変化がなかった症例 は鈎部癌 3 例と，頭部癌切除例の 1 例であった。 頭部癌43例中 39 例, 体部癌 7 例中 6 例, 計 45 例は 尾側膵管が拡張していた。

閒脈系への癌浸潤は頭部癌で35例70\%，体尾部 癌で 25 例 $93 \%$ ，全体癌で 6 例 $100 \%$ あ゙あった。こ の5ち切除例では頭部癌 8 例 $44 \%$, 尾部癌 1 例 33 \%であった。

膵癌は被膜をこえて浸潤・増殖すると，䇟接臟 器へ浸潤し，門脈壁に沿って進展する。肝転移を 含め膵癌の進展様式を検討した（図 1，2）.

進展様式を，1）胃・結腸に浸潤する前方浸潤， 2 ) 後腹膜, 腹部大動脈, 下大静脈に浸潤する後 方浸潤，3）肝・十二指晹靶带内を肝門部に向っ て浸潤する上方浸潤，4）腸間膜根部に向って浸 潤する下方浸潤に分類した。

前方浸潤は頭部癌で 6 例 $12 \%$ ，体尾部癌で17例 $61 \%$ ，全体癌で 5 例 $83 \%$ であった。後方浸潤は頭 部癌で11例 $22 \%$ ，体尾部癌で20例 $71 \%$ ，全体癌で 3 例 $50 \%$ でめった. 上方浸潤は頭部癌で 6 例 12 $\%$ ，鈎部癌で 2 例 $29 \%$ ，体尾部癌で 10例 $36 \%$, 全

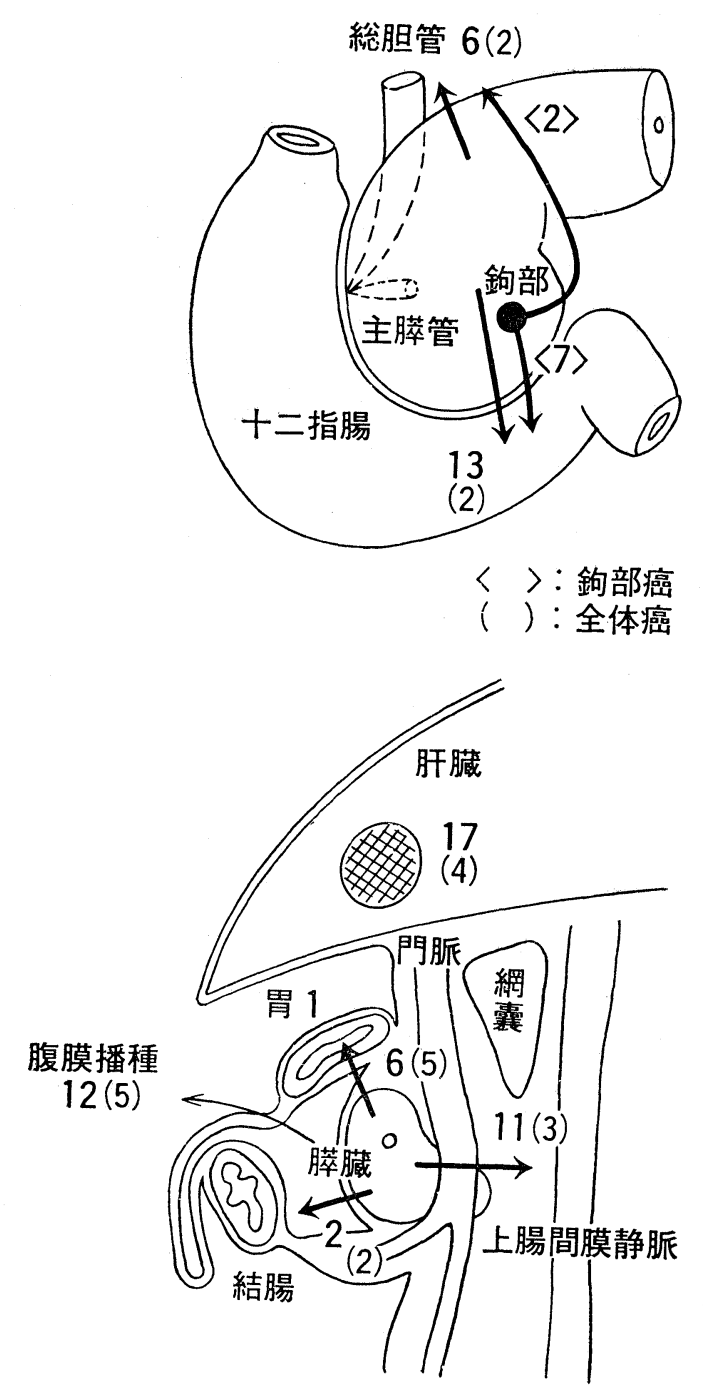

大動脈/下大静脈

図 1 橧癌の進展様式(1)：

頭部癌 $(n=50)$ と全体癌 $(n=6)$

体癌で 2 例 $33 \%$ であった．下方浸潤は頭部癌で 13 例 $26 \%$, 鈎部癌で 7 例 $100 \%$, 体尾部癌で 7 例25 $\%$ ，全体癌で 2 例 $33 \%$ であった。

進展様式を癌の線維性基質量の多寊之腫瘍の大 きさとの関係で検討すると，前方・後方浸潤は基 質量の差に関係なく，腫㾤が大きくなるにしたが って頻度が高くなる傾向がみられた，上方・下方 


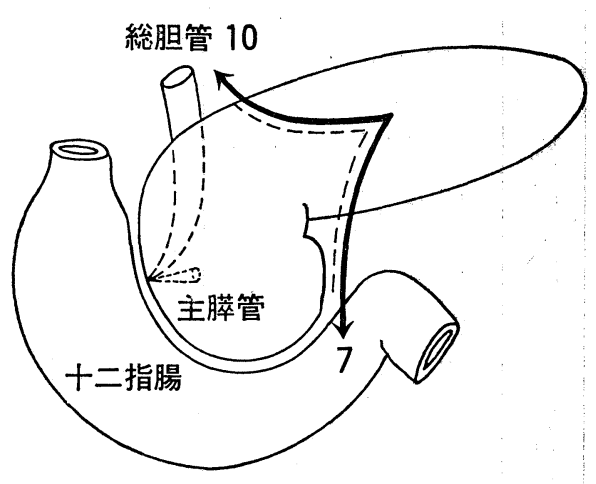

\begin{tabular}{|c|c|c|c|c|c|c|}
\hline & \multicolumn{3}{|c|}{ 前 方 浸 潤 } & \multicolumn{3}{|c|}{ 後 方 浸 潤 } \\
\hline & $1 \sim 3 \mathrm{~cm}$ & $3 \sim 6 \mathrm{~cm}$ & $6 \mathrm{~cm} \sim$ & $1 \sim 3 \mathrm{~cm}$ & $3 \sim 6 \mathrm{~cm}$ & $6 \mathrm{~cm} \sim$ \\
\hline $\begin{array}{r}\text { 線維性基質量 } \uparrow \\
(\mathrm{n}=24)\end{array}$ & $\begin{array}{c}2 / 6 \\
(33 \%)\end{array}$ & $\begin{array}{l}3 / 10 \\
(30 \%)\end{array}$ & $\begin{array}{c}7 / 8 \\
(88 \%)\end{array}$ & $\begin{array}{c}2 / 6 \\
(33 \%)\end{array}$ & $\begin{array}{l}6 / 10 \\
(60 \%)\end{array}$ & $\begin{array}{l}5 / 8 \\
(63 \%)\end{array}$ \\
\hline $\begin{array}{r}\text { 線維性基質量 } \downarrow \\
(n=34)\end{array}$ & $\begin{array}{c}1 / 2 \\
(50 \%)\end{array}$ & $\begin{array}{l}3 / 13 \\
(23 \%)\end{array}$ & $\begin{array}{l}10 / 19 \\
(53 \%)\end{array}$ & $\begin{array}{l}1 / 2 \\
(50 \%)\end{array}$ & $\begin{array}{l}4 / 13 \\
(31 \%)\end{array}$ & $\begin{array}{l}12 / 19 \\
(63 \%)\end{array}$ \\
\hline
\end{tabular}

\begin{tabular}{|c|c|c|c|c|c|c|}
\hline & \multicolumn{3}{|c|}{ 上方 浸 潤 } & \multicolumn{3}{|c|}{ 下 方 浸 潤 } \\
\hline & $1 \sim 3 \mathrm{~cm}$ & $3 \sim 6 \mathrm{~cm}$ & $6 \mathrm{~cm} \sim$ & $1 \sim 3 \mathrm{~cm}$ & $3 \sim 6 \mathrm{~cm}$ & $6 \mathrm{~cm} \sim$ \\
\hline $\begin{array}{r}\text { 線維性基質量 } \uparrow \\
(n=24)\end{array}$ & $\begin{array}{c}3 / 6 \\
(50 \%)\end{array}$ & $\begin{array}{l}1 / 10 \\
(10 \%)\end{array}$ & $\begin{array}{c}5 / 8 \\
(63 \%)\end{array}$ & $\begin{array}{c}1 / 6 \\
(17 \%)\end{array}$ & $\begin{array}{l}3 / 10 \\
(30 \%)\end{array}$ & $\begin{array}{c}5 / 8 \\
(63 \%)\end{array}$ \\
\hline $\begin{array}{r}\text { 線維性基質量 } \downarrow \\
(n=34)\end{array}$ & $\begin{array}{c}2 / 2 \\
(100 \%)\end{array}$ & $\begin{array}{l}4 / 13 \\
(31 \%)\end{array}$ & $\begin{array}{l}1 / 19 \\
(5 \%)\end{array}$ & $\begin{array}{l}1 / 2 \\
(50 \%)\end{array}$ & $\begin{array}{l}6 / 13 \\
(46 \%)\end{array}$ & $\begin{array}{l}5 / 19 \\
(26 \%)\end{array}$ \\
\hline
\end{tabular}

表 3 膵癌の進展様式と基質量の差, 腫瘍の大きさ

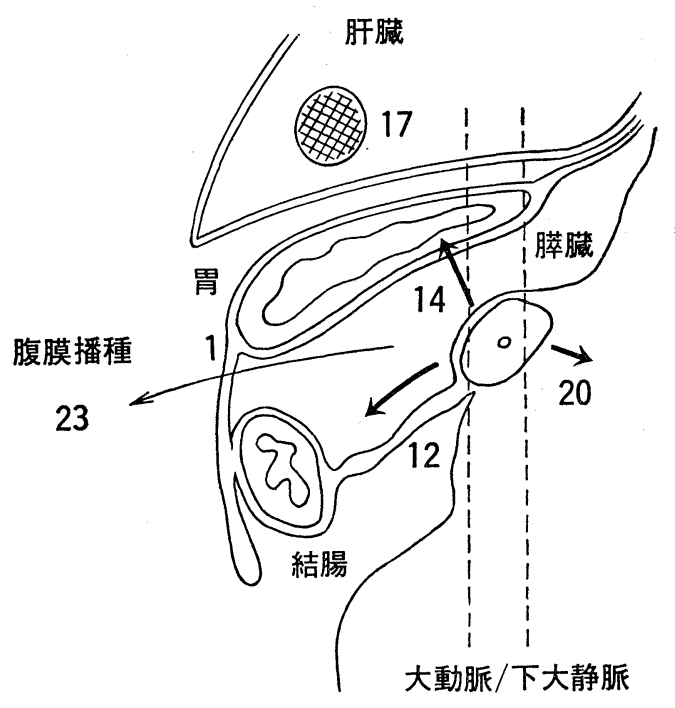

図 2 膡癌の進展様式(2)： 体尾部癌 $(\mathrm{n}=27)$

浸潤は基質量の多い癌は大きさが増すにつれて頻 度が高くなり，基質量の少ない癌では大きさと浸 潤の頻度の間に相関はなかった。この結果，基質 量の多い癌は膵外に浸潤すると, 上方・下方に進 展する傾向があることがわかった，基質量の少な い癌は膨張性に発育・浸潤することがほとんど で，方向性をもつ傾向は少ない（表 3 ）.

肝転移は頭部癌で17例 $34 \%$, 体尾部癌で17例 61 $\%$, 全体癌で 4 例 $67 \%$ そられた。基質量との関 係では, 基質量の多い癌では36例中 9 例 $25 \%$, 少 ない癌では37例中 26 例70\%に認められた。肝転移

\begin{tabular}{|c|c|c|c|c|}
\hline \multirow{2}{*}{ 血管造影所見 } & \multirow{2}{*}{ 型 } & \multirow{2}{*}{ シェーマ } & \multicolumn{2}{|c|}{ 肉 眼 所 } \\
\hline & & & 線維性基質 & 線維性基質 $\downarrow$ \\
\hline \multirow{4}{*}{ Encasement } & 1型 & mmm- & $24 \%$ & $22 \%$ \\
\hline & 2型 & $\approx \approx \approx \approx n$ & $79 \%$ & $50 \%$ \\
\hline & 3型 & 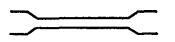 & $36 \%$ & $72 \%$ \\
\hline & 4型 & 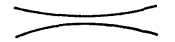 & $0 \%$ & $9 \%$ \\
\hline \multirow{3}{*}{ 閉 塞 像 } & 1型 & 领々，朎 & $21 \%$ & $28 \%$ \\
\hline & 2型 & $1 \longdiv { = }$ & $18 \%$ & $15 \%$ \\
\hline & 3型 & $1 \rightleftharpoons$ & $6 \%$ & $15 \%$ \\
\hline
\end{tabular}

表 4 膵癌の動脈の Encasement - 閉塞像の型別分 類と肉眼所見

は基質量が少ない癌に多かった。

B. 血管造影所見と病理所見の対比

1. 血管造影所見々肉眼所見

脺癌の血管造影所見は動脈の不整な狭窄 (encasement）・閉塞がその主な造影所見で，癌は腫 湯血管に乏しく，無血管領域としてみられる788322 42)43).

膵癌の動脈の roentgenogram を作製した27例 の造影所見を分析し，病理所見と比較検討した.

Encasement，閉塞像を表 4 亿示すよ5 亿分類 し, 肉眼所見と対比した.

線維性基質量の多い癌では 2 型のencasement, 少ない癌では 3 型のencasement が高頻度で, 4 型 の encasement は基質量の少ない癌だけに認めら れた。閉塞像は基質量に関係なく 1 型が高頻度に 認められたが， 3 型は基質量の少ない癌に多くみ 
られる傾向にあった。

大きさの要素を入れて検討した. $6 \mathrm{~cm}$ 以下の癌 では, encasement 各型の頻度は基質量の多い癌 で15\%，77\%，19\%，0\%，基質量の少ない癌で27 \%，40\%. 93\%，6\%と差がなかった. 閉塞像各 型の頻度は，基質量の多い癌で 19\%，23\%，0

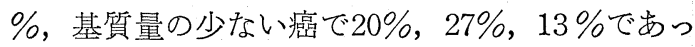
た. 3 型の閉塞像は基質量の多い癌にはみられな かった. $6 \mathrm{~cm}$ 以上の癌では肉眼所見に関係なく, 2 型の encasement $486 \% ， 100 \% ， 3$ 型は $59 \%$, $53 \%$ とほぼ同じ頻度であり，閉塞像の各型は基質 量の多い癌で $27 \%, 0 \%, 9 \%$, 少ない癌で 35 $\% ， 6 \% ， 18 \%$ と，2 型より 3 型が多く又られる 傾问にあった。

この結果から，いろいろな形の encasement は, 癌の線維性基質量の差による表現の違いであ ることがわかった。

2. 動脈の encasement と閉塞像の病理

a . Encasement の病理 ${ }^{44)}$

Roentgenogram 上 2 型の encasement を示し た11例， 3 型 2 例， 4 型 1 例で，動脈を含めた組 織連続標本を作製して，その成因を研究した。

2 型では, 動脈の変形・縮小は 11 例 $100 \%$ であ った．動脈の長径・短径は不規則に変っており, 同時に動脈内腔も変形していた。内膜肥厚は 7 例 64\%，動脈壁への癌浸潤は外膜までで， 3 例 $27 \%$ であった。動脈周囲では，全例膠原線維束が著し く同心円状に增生していた。

3 型では動脈の変形はごく軽度で，縮小は 2 例 $100 \%$ あっったが，内膜肥厚はなかった．動脈壁 への癌浸潤は 1 例で，疎開した中膜筋間を外膜か ら内膜近くまで連綄性に浸潤していた。外膜周囲 では 2 例共同心円状飞增生する膠原線維束がみら れたが，その程度は 2 型に比べると柽度であっ た。

4 型の組織所見は 3 型と同様に 動脈の縮小がみ られたが，変形・内膜肥厚はなく，動脈が全体に 縮小した所見を示した。動脈壁への癌浸潤はな く, 外膜周国で增生している膠原線維束は他の 2 つの型に比べると軽度であった。

\begin{tabular}{|c|c|c|}
\hline & 造影所見と腫瘍 & $\begin{array}{l}\text { 異常所見部位から } \\
\text { 腫湯の境界までの距離 }\end{array}$ \\
\hline \multirow{3}{*}{$\begin{array}{l}\text { 膵 } \\
\text { 内 } \\
\text { 動 } \\
\text { 脈 }\end{array}$} & $\stackrel{H}{H}{ }_{(n=2)}^{H}$ & Ca. $2 \mathrm{~mm} .3 \mathrm{~mm}$ \\
\hline & $1 \mapsto n$ & Ca. $3 \mathrm{~mm}$ \\
\hline & $1 \stackrel{H}{H} \quad$ & Ca. $2 \mathrm{~mm}$ \\
\hline \multirow{3}{*}{$\begin{array}{l}\text { 膵 } \\
\text { 外 } \\
\text { 動 } \\
\text { 脈 }\end{array}$} & $\stackrel{H}{P=w_{(n=2)}^{H}}$ & Ca. $5 \mathrm{~mm}$ \\
\hline & ${ }^{+1+1}$ & Ca. $5 \mathrm{~mm}$ \\
\hline & 15 & Ca. $10 \mathrm{~mm}$ \\
\hline
\end{tabular}

表 5 Roentgenogram の造影所見と膵癌の浸潤範囲

以上の結果から， 2 型と 3 ・ 4 型の違いは主に 外膜周囲で增生する膠原線維束の密度の差で, と くに 2 型では, 部位により desmoplastic reaction の程度に差が生じて動脈を不規則にしめつけるた め, 動脈の長径・短径が部位により変化するもの と推測できた。

\section{b. 閉塞像の病理 ${ }^{45}$}

動脈の閉塞像は, 病理学的には encasement の 終末像であった. Roentgenogram 上 1 型の閉塞 像を示した 3 例， 2 型を示した 3 例で, encasement 同様に動脈を含めた組織連続標本を作製し てその成因を研究した。

1 型では 3 例共, 動脈の変形々縮小がみられ た. 2 例に内膜肥厚があり, 同部位で幼若な肉芽 組織の形成が認められた. 内腔の閉塞がみられた のは 2 例で，共に癌が外膜周囲から動脈内腔にま で連続性に浸潤していた。

2 型も同様で， 3 例共動脈は変形・縮小し， 2 例に内膜肥厚が認められた。1例で動脈内腔は閉 塞して特り，内腔は幼若な肉芽組織だけで閉塞さ れていた。動脈壁への癌浸潤は 1 例にみられ, 癌 は疎開した中膜筋間を伝わり，内膜まで浸潤して いた。

動脈内腔の閉塞があった症例は何れも進行癌 で，閉塞がなかった 3 例中 2 例は切除例であっ た。 


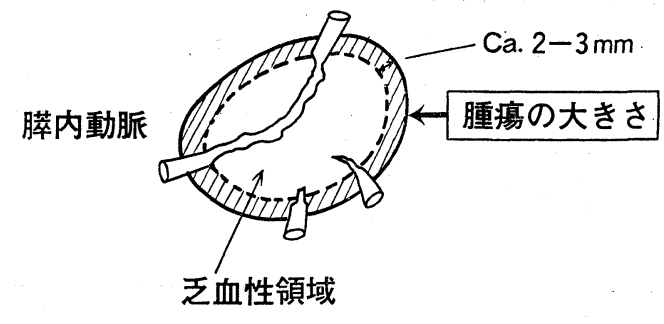

〔膵内限局型癌〕

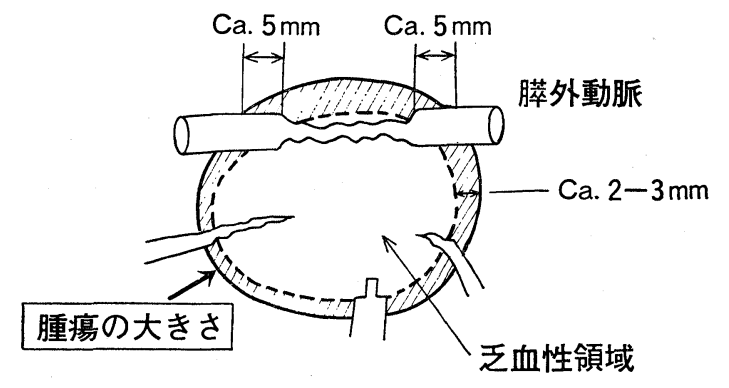

〔進行膵癌〕

図3 Roentgenogram の造影所見と予測できる 膵癌の大きさ

\section{3. 大きさの診断}

Roentgenogram 上異常所見部位から正常部位 にかけて連続標本を作製した 8 例について，血管 造影所見と癌浸潤の範囲を検討した。つぎに 27 例 について，血管造影所見から肉眼的癌の大きさの 診断能を調べた。

膵内動脈の encasement, 閉塞がみられる部位 から, 組織学的に癌浸潤は約 $2 \sim 3 \mathrm{~mm}$ の範囲に拡 がっていた．膵外動脈では encasement の場合は 約 $5 \mathrm{~mm}$, 閉塞の場合は約 $10 \mathrm{~mm}$ の範囲まで癌が浸潤 していた（表 5 ).

以上の結果から, 膵内動脈では $2 \sim 3 \mathrm{~mm}$, 膵外 動脈では約 $5 \mathrm{~mm}$ の幅をもたせて 動脈の異常所見部 位をプロットして(図 3)，27例の癌の大きさの血 管造影診断能を検討した。

切除例では膵内限局型癌 6 例, 膵外浸潤型癌 7 例全例に，癌の大きさが正確に診断できた. 進行

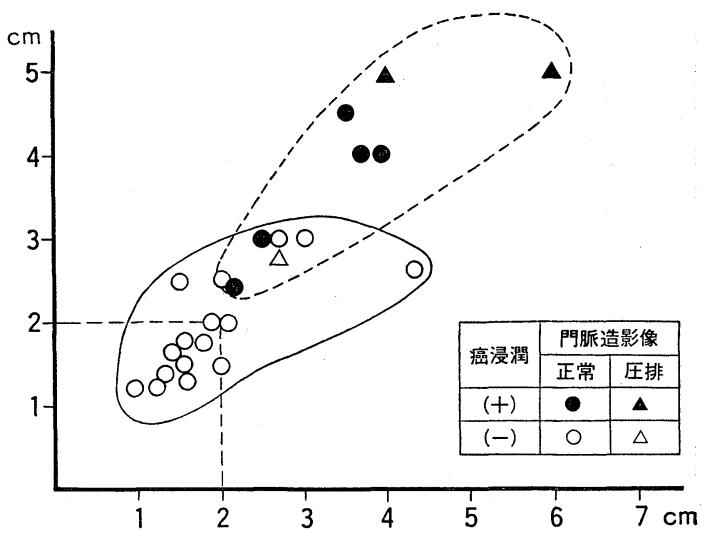

表 6 膵癌の大きさと閒脈浸潤

癌では14例中 8 例が正診， 6 例は膵外での浸潤範 囲が広く，動脈所見だけからは診断できなかっ た。

4. 門脈系への癌浸潤

血管造影で閒脈の狭窄，閉塞がみられれば，癌 浸潤による変化であるといえる。これら所見は剖 検で確かめた．門脈が正常か圧排されている時の 門脈浸潤の有無について, 切除19例, 膵内限局型 癌 5 剖検例を対象として調べた。

造影所見が正常であった 21 例中 5 例 $24 \%$ ，圧排 を示した 3 例中 2 例に門脈浸潤があった.

癌の大きさとの関係をみると, 門脈正常例では $2 \mathrm{~cm}$ 以下の症例に閒脈浸潤はなかった. $2 \sim 3 \mathrm{~cm}$ の癌では 8 例中 2 例 $25 \%, 3 \mathrm{~cm}$ 以上の癌では 4 例 中 3 例75\%に門脈浸潤が認められた。 圧排像を示 した症例は全例 $3 \mathrm{~cm}$ 以上の癌で, $3 \mathrm{~cm}$ の癌の 1 例 にだけ門脈浸潤がなかった（表 6 ）.

閒脈造影所見が正常であった $2 \mathrm{~cm}$ 以下の頭部癌 13例について, 動脈の異常所見の数, 部位, 呫よ び腫漡の大きさと閒脈浸潤の関係を検討した. 膵 前・後アーケード, 背側膵動脈の膵外動脈に近い 領域を $\mathrm{A}$, 離れた部位をBとして分けた. 2 ～ 3 $\mathrm{cm}$ の大きさの癌は 5 例で, 動脈の変化が薪内動脈 に限局していた 4 例は, 占居部位に関係なく浸潤 はなかった. 膵外動脈に変化のあった 1 例には, 浸潤が認められた. $3 \mathrm{~cm}$ 以上の癌では, 動脈の変 化が 1 つの膵内動脈に限局している症例のう,ち, 


\begin{tabular}{|c|c|c|c|}
\hline \multirow{2}{*}{ 腫瘍の大きさ } & 被 & 膜 & 潤 \\
\hline & Co & $\mathrm{Ci}$ & $\mathrm{Ce}$ \\
\hline $1 \sim 2 \mathrm{~cm}$ & 3 & 2 & 2 \\
\hline $2 \sim 3 \mathrm{~cm}$ & 0 & 0 & 3 \\
\hline $3 \sim 4 \mathrm{~cm}$ & 1 & 1 & 1 \\
\hline $4 \sim 5 \mathrm{~cm}$ & 1 & 0 & 3 \\
\hline
\end{tabular}

co: 被膜浸潤なし。ci：被膜浸潤あり。ce：膵被膜をこえて浸潤している。

表 7 膵癌の被膜漫潤と大きさ（門脈正常例17例）

$\mathrm{A}$ 領域の 1 例には浸潤があり， $\mathrm{B}$ 領域の 1 例には 浸潤がなかった. 2 つ以上の猝内動脈に変化のあ った 5 例は全例 $\mathrm{A}$ 領域に存在し， 3 例に浸潤が認 められた。

以上の結果から，血管造影で閒脈が正常でも， 癌が萃外動脈近い領域に局在し，大きさが $3 \mathrm{~cm}$ 以上であれば門脈浸潤の確率が高いことが明らか になった。

\section{5 . 膵被膜浸潤}

門脈が正常であった切除15例，膵内限局型癌 2 剖検例，計17例で血管造影の膵被膜浸潤の䛦断能 を検討した。

組織学的に 17 例中 5 例は被膜内に限局し，3 例 に被膜浸潤，9例に被膜をこえて浸潤している所 見を認めた（表 7).

動脈の異常所見の数，部位と腫瘍の大きさとの 関係で，被膜浸潤の有無について検討した.

$\mathrm{A}$ 領域の癌では，動脈の異常所見の数や大ささ に関係なく，9例中 7 例に被膜浸潤があった。 B 領域の癌では, $1 \sim 2 \mathrm{~cm}$ の癌 4 例中 2 例に被膜浸 潤，2 例に被膜外浸潤があり，2〜 $5 \mathrm{~cm}$ の大ささ の癌ではそれぞれ1例ずつ認められた。

以上の結果から，膵外動脈飞近い領域の癌は, 小さな癌でも被膜外浸潤の可能性は高いと予測で さるが，膵外動脈から離れた領域の癌は，大きさ に関係なく被膜浸潤の診断はできないことがわか った.

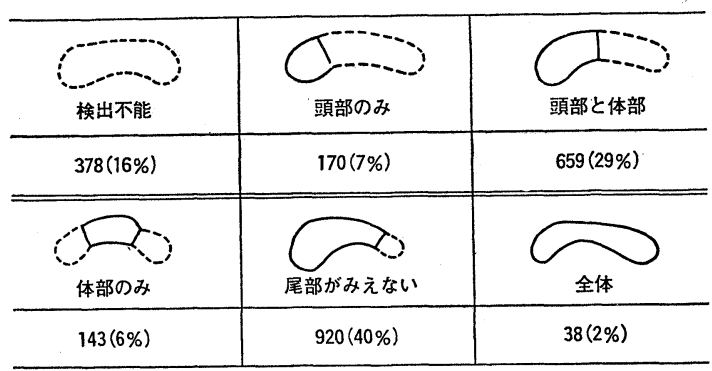

図 4 U S の膵検出能 $(\mathrm{n}=2308)$

順天堂大学消化器内科（1972～1981）

\section{C.X線，ならびに超音波診断}

\section{1. 超音波検查}

$\mathrm{US}$ の膵検出能を 2,308 例で検討した. 検出不能 $16 \%$ ，頭部のみ $7 \%$ ，頭体部 $29 \%$ ，体部のみ 6 \%，尾部がみえない $40 \% ，$ 全体がみえたのは $2 \%$ で，頭体部の検出能は良かったが，尾部の検出能 は極めて悪かった（図 4).

これらの症例のうち，膵に異常ありとUSで晾 断したのは236例で, そのうち膵癌は28例であっ た.

膵癌のUS所見は，びまえ性腫大 1 例 $4 \%$, 限 局性腫大 17 例 $60 \%$ ，限局性腫大十膵管拡張 7 例 25 $\%$, 膵管拡張の久 2 例 $7 \%$, 胆囊腫大 /胆管拡張 14 例 $50 \%$ ，肝転移 5 例 $18 \%$ であった。なお，腹水 貯溜のため検出不能な症例が 1 例あった.

診断能は, sensitivity $25 / 28=89 \%$, specificity 2072/2302=90\%であった．部位別䛦断能を及る と, 頭部癌 12 例中 10 例 $83 \%$, 体尾部癌14例中 13例 $93 \%$ ，全体癌 2 例中 2 例 $100 \%$ ，占居部位に関 係なく診断能は高い。

大きさ別による診断能は，組織確䛦例19例で検 討すると， $2 \mathrm{~cm}$ 以下の癌は 3 例共診断できなかっ た (表 8 ). 3 例中 2 例は尾側萃管の拡張は診断で きた。

2.コンピューター断層撮影

脺疾患が疑われた79例にC Tを施行し，膵癌 28 例を揨断した。

膵癌の C T所見は，限局性腫瘤 22 例 $78 \%$, 限局 性腫瘤十萃管拡張 2 例 $7 \%$, 膵管拡張の夕 2 例 7 $\%$, 胆囊腫大 $/$ 胆管拡張10例36\%, 周囲脂肪織の 


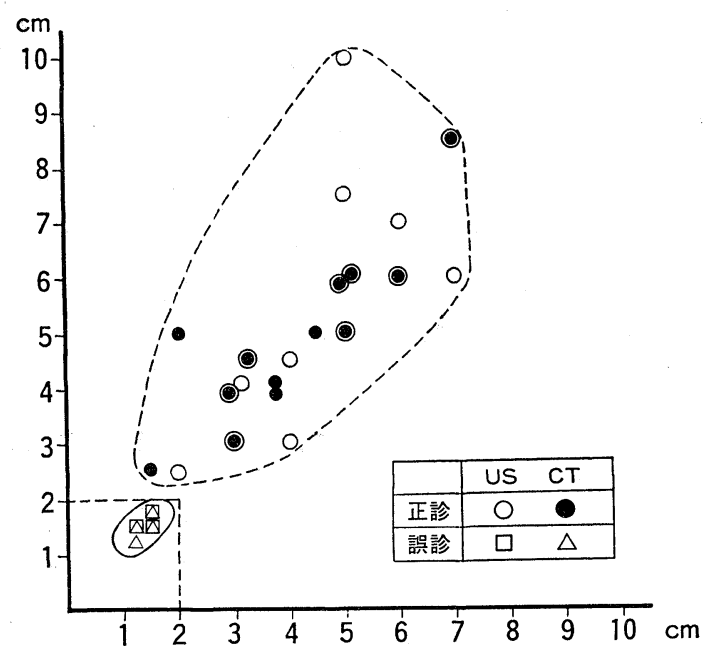

表 8 膵癌の大きさとU S, C T の診断能 順天堂大学消化器内科（1972～1982）

消失15例 $54 \%$, 肝転移 8 例 $29 \%$, 正常萃 1例 $4 \%$ で，るいそうが著しかった 1 例は膵の検出ができ なかった。

唁断能は, sensitivity $24 / 28=86 \%$, specificity 28/51=55\%であった．部位別診断能をみると頭 部癌13例中 11 例 $85 \%$, 体尾部癌 15例中 13 例 $87 \%$ で, U S 同様，腫瘍占居部位に関係なく診断能は 高かった.

大きさ別に診断能をみると， $2 \mathrm{~cm}$ 以下の癌は 4 例共診断できなかった（表 8).

3. 内視鏡的膵・胆管造影

E R C P 施行例 3, 209例中, 膵 ・胆管への插管率 は3,101例 $97 \%$ で，目的別にみると萃管への挿管率 は2,246例92\%であった。

膵癌95例中 86 例に膵管像が党られた。主膵管の 閉塞は 46例 $57 \%$ そられ，断裂は33例，先細り型 は16例であった，主膵管の狭窄と尾側膵管の拡張 は26例30\%，主膵管が閉塞し，その周囲に造影剤 の管外漏出がみられたのは 6 例 $7 \%$ ，分枝だけの 閉塞は 5 例 $6 \%$ あった。

診断能は, sensitivity $79 / 83=95 \%$, specificity $2163 / 2246=96 \%$ で, 有所見率は $82 / 83=99 \%$ で あった．部位別診断能をみると，頭部癌 58 例中 56

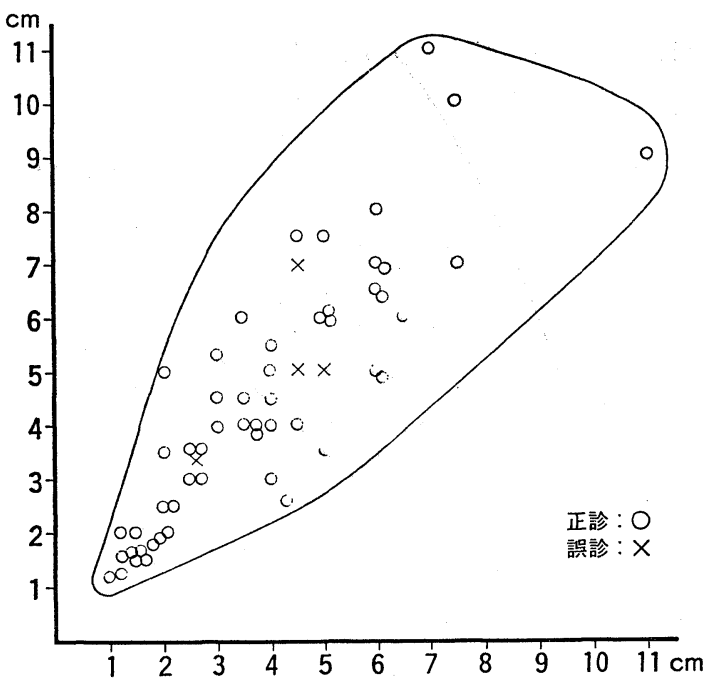

表 9 膵癌の大きさと E R C P の診断能

順天堂大学消化器内科（1977～1982）

\begin{tabular}{|c|c|c|}
\hline \multirow{3}{*}{ 動 脈 相 } & Encasement & $100(89 \%)$ \\
\cline { 2 - 3 } & 閉 塞 像 & $53(47 \%)$ \\
\cline { 2 - 3 } & 偏 位 & $12(11 \%)$ \\
\hline \multirow{3}{*}{ 毛細管 相 } & 乏血 性 & $92(82 \%)$ \\
\cline { 2 - 3 } & 動脈新生 & $7(6 \%)$ \\
\cline { 2 - 3 } & 多血 性 & $6(5 \%)$ \\
\hline \multirow{3}{*}{ 静 脈 相 } & 正 常 & $25(22 \%)$ \\
\cline { 2 - 3 } & 圧 排 & $8(7 \%)$ \\
\cline { 2 - 3 } & 狭窄, 閉塞 & $78(70 \%)$ \\
\hline
\end{tabular}

表10 膵癌の血管造影所見 $(\mathrm{n}=112)$

順天堂大学消化器内科（1972～1982）

例 $97 \%$, 体尾部癌33例中 30 例 $94 \%$, 全体癌 2 例中 2 例 $100 \%$ であった。

大きさとの関係を検討すると，最小 $1.2 \times 1.0 \mathrm{~cm}$ から最大 $9 \times 11 \mathrm{~cm}$ の癌まで㟝断できた（表 9 ）.

4. 血管造影

脺疾患を疑った 198例に血管造影を行い，112例 の膵癌を診断した．血管造影所見は，動脈相では encasement が89\%と最も頻度が高く，閉塞像は 47\%であった。毛細管相では 82\%の症例がそ血性 病変として認められた。静脈相では $77 \%$ に門脈系 静脈の異常がみられた（表10）. 


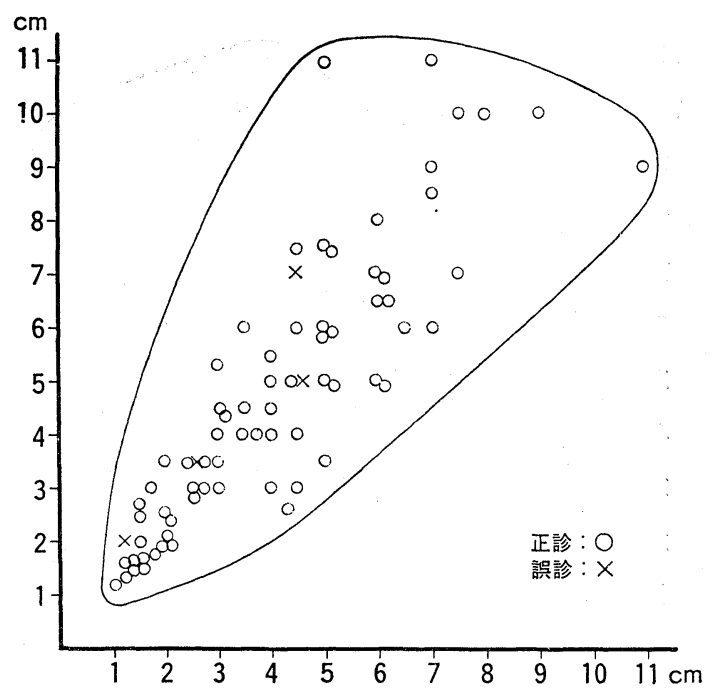

表11 膵癌の大きさと血管造影の診断能

順天堂大学消化器内科（1977～1982）

\begin{tabular}{|c|c|c||c||c|c|}
\hline & US & CT & US +CT & ERCP & 血管 造 影 \\
\hline 前方浸潤 & $2 / 4(50 \%)$ & $4 / 5(80 \%)$ & $1 / 3 \uparrow$ & & $8 / 15(53 \%)$ \\
\hline 後方浸潤 & $2 / 5(40 \%)$ & $4 / 5(80 \%)$ & $2 / 4 \uparrow$ & & $10 / 22(45 \%)$ \\
\hline 上方浸潤 & $2 / 3(67 \%)$ & $0 / 3(0 \%)$ & $2 / 2 \uparrow$ & $3 / 8(38 \%)$ & $7 / 8(88 \%)$ \\
\hline 下方浸潤 & $0 / 2(0 \%)$ & $0 / 1(0 \%)$ & $0 / 1 \rightarrow$ & & $14 / 15(93 \%)$ \\
\hline 肝転移 & $4 / 6(67 \%)$ & $4 / 4(100 \%)$ & $2 / 4 \uparrow$ & & $20 / 27(74 \%)$ \\
\hline
\end{tabular}

表12 各種検査法の膵癌進展様式の診断能 $(n=48)$ 順天堂大学消化器内科（1972～1982）

診断能は, sensitivity $108 / 112=96 \%$, specificity $80 / 86=93 \%$ であった。部位別晾断能は頭部 癌 $74 / 75=99 \%$, 体尾部癌 $27 / 30=90 \%$, 全体癌 $7 / 7=100 \%$ で，他検査法と同様に診断能は高かっ た。

組織確崄76例で血管造影の診断能を検討する と，腫瘍の大きさの診断は $70 / 76=92 \% ， \quad$ 門脈浸 潤 $49 / 58=84 \%$ ，切除可否の䛦断 $25 / 26=96 \%$ であ った．搭内限局型癌でめるかの診断能は，16/20 $=80 \%$ であった.

血管造影の䛦断能と膵癌の大きさの関係をみる と, 最小病変 $1.2 \times 1.0 \mathrm{~cm}$ 员最大病変 $9 \times 11 \mathrm{~cm}$ 要 で診断できた（表11）。

\section{D. 総合診断}

\begin{tabular}{|c|c|c|c|c|}
\hline 腫靎の大きさ & US & CT & ERCP & 血管造影 \\
\hline $1 \sim 2 \mathrm{~cm}$ & $2 / 2^{*}$ & $2 / 3^{*}$ & $6 / 6$ & $6 / 6$ \\
\hline $2 \sim 3 \mathrm{~cm}$ & $1 / 1$ & $1 / 1$ & $4 / 4$ & $5 / 5$ \\
\hline $3 \sim 6 \mathrm{~cm}$ & & $3 / 3$ & $6 / 7$ & $7 / 8$ \\
\hline $6 \mathrm{~cm} \sim$ & & & $2 / 2$ & $2 / 2$ \\
\hline
\end{tabular}

表13 膵癌の大きさ別による診断能

\% 膵管拡張のみ

順天堂大学消化器内科（1972～1982）

\begin{tabular}{|c|c|c|c|c|}
\hline 原埥の大きさ & US & CT & ERCP & 血 管 造 影 \\
\hline $1 \sim 3 \mathrm{~cm}$ & $1 / 3(33 \%)$ & $0 / 4(0 \%)$ & $5 / 10(50 \%)$ & $11 / 11(100 \%)$ \\
\hline $3 \sim 6 \mathrm{~cm}$ & & $3 / 3(100 \%)$ & $1 / 7(14 \%)$ & $7 / 8(88 \%)$ \\
\hline $6 \mathrm{~cm} \sim$ & & & $0 / 2(0 \%)$ & $2 / 2(100 \%)$ \\
\hline
\end{tabular}

表14 膵癌の大きさの診断

順天堂大学消化器内科（1972～1982）

\section{1. 進展様式の診断能}

進行した膵癌は後腹膜を門脈壁に沿って上方・ 下方に浸潤し，あるいは胃・結腸，大動脈，下大 静脈に直接浸潤して切除不能となる。肝転移も切 除不能な要因の 1 つである. 各種検査法の, 進展 様式の䛦断能を検討した（表12）.

前方・後方浸潤共にC T の䛦断能は $80 \%$ と良好 で，US，C Tを組み合わせると，前者で 3 例中 1 例, 後者で 4 例中 2 例に診断能の向上が認め られた，血管造影の診断能はそれぞれ $53 \% ， 43 \%$ で，横断面で癌の進展をとらえることのできる C Tの䛦断能が優れていた. 上方浸潤は, 胆管拡 張，閉塞部位をいろいろな方向から 検 査できる USがC Tより優れて㧤り，両検査法を併用する と，2 例中 2 例飞䛦断能の向上が認められた. E R C P は膵管・胆管を同時に造影することによ り上方浸潤だけは䛦断できるが，38\%の正診率で しかなかった．血管造影は $88 \%$ と診断能は高かっ た．下方浸潤はUS，CT共に彮断できなかっ た. 血管造影は $93 \%$ と高率に㟝断可能であった。 肝転移はUS，C T 共に高い䛦断能を示し，両検 查法そ併用すると，4 例中 2 例に䛦断能が向上し た. 血管造影診断能は74\%であった。 


\begin{tabular}{|c|r|r|}
\hline & \multicolumn{1}{|c|}{ 切 除 例 } & 非 切 除例 \\
\hline US & $3 / 3 *(100 \%)$ & $24 / 25(96 \%)$ \\
\hline CT & $6 / 7 *(86 \%)$ & $20 / 21(95 \%)$ \\
\hline ERCP & $19 / 20(95 \%)$ & $69 / 72(96 \%)$ \\
\hline 血管造影 & $20 / 21(95 \%)$ & $88 / 91(97 \%)$ \\
\hline
\end{tabular}

※膵管拡張, US ·CT 共に 2 例

表15 膵癌切除例, 非切除例の診断能の比較

$$
(\mathrm{n}=122)
$$

順天堂大学消化器内科（1972～1982）

\begin{tabular}{|c|c|c|}
\hline & \multicolumn{1}{|l|}{$\begin{array}{l}\text { Positive Predictive } \\
\text { Value }\end{array}$} & $\begin{array}{l}\text { Negative Predictive } \\
\text { Value }\end{array}$ \\
\hline US & $28 / 236=12 \%$ & $2072 / 2075=99 \%$ \\
\hline CT & $24 / 47=51 \%$ & $28 / 32=87 \%$ \\
\hline ERCP & $79 / 134=59 \%$ & $2163 / 2169=99 \%$ \\
\hline 血管造影 & $108 / 114=95 \%$ & $80 / 84=95 \%$ \\
\hline
\end{tabular}

表16 各種検查法の膵癌診断能の信頼度

順天堂大学消化器内科（1972～1982）

\section{2. 切除例の検討}

切除 21 例で大きさ別に搒断能を検討すると， 1 〜 $2 \mathrm{~cm}$ の大ささ癌は, U S, C T 共に膵管, 胆 管の拡張しか診断できなかった. $2 \mathrm{~cm}$ 以上の癌 は，US，CＴ共に他検查法と同㥞に診断能は高 かった. E R C P, 血管造影は腫瘍の大ささに関 係なく診断能の高い検査法であった（表13）.

腫瘍の大きさの診断能をみると，US， C T は 小さな癌の診断能は極めて悪いか, 不能であり, E R C P は小さな癌ほど良かった。血管造影は 1 cm以上の癌であれば，正確に診断できた（表14).

3 . 形態学的検査法の診断能の考察

切除21例, 非切除101例について, US, C T, E R C P, 血管造影の診断能を比較した. 各種検 查法の診断能は切除例で 95\%から $100 \%$, 非切除 例で $95 \%$ か 97\%と高い彮断能を示し, 有意の差 はなかった（表15）.

そこで, これら検査法の positive predictive value (PPV), すなわち癌を疑ら所見が陽性にみ

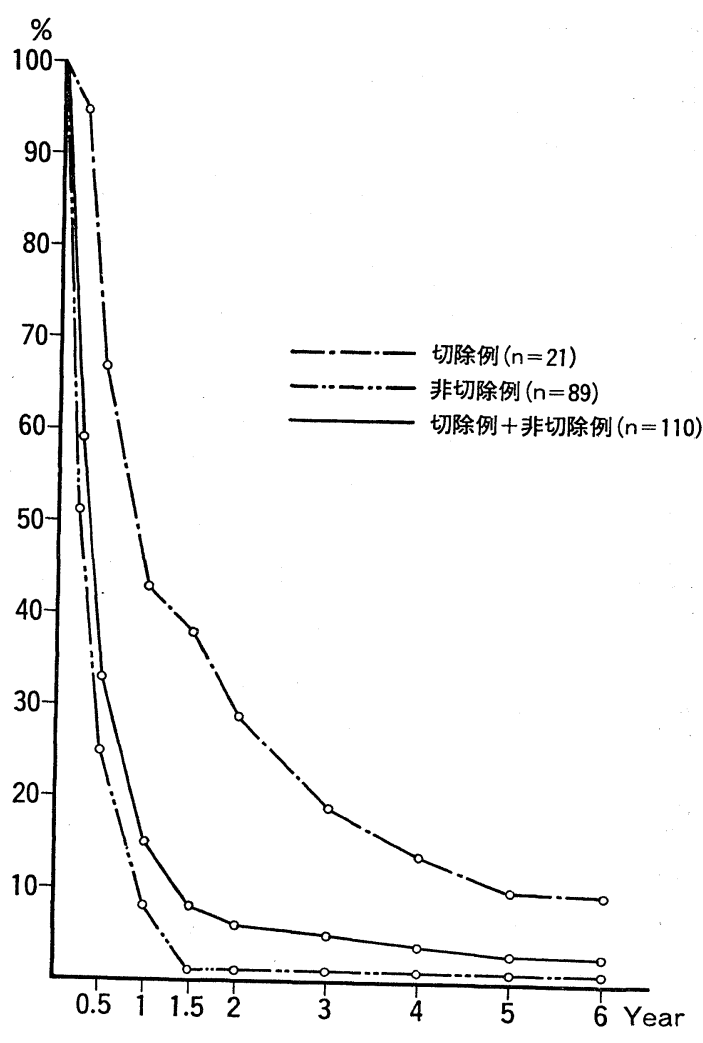

表17 膵癌の予後

順天堂大学消化器内科（1972～1982）

られた時, 実際に癌がある確率と, negative predictive value (NPV)，すなわち膵に異常がない と誩断した時, 癌がない確率を計算した。

U S の P P Vは $12 \%$ と低く, 癌と晾断した場合 の信頼度は低い. N P Vは $99 \%$ ， その信頼度は 高い.C TのP P Vは50\%，N P Vは87\%，ER

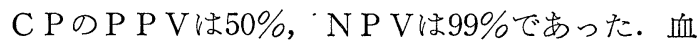
管造影の P P V，N P V は共に95\%と信頼度が高 かった（表16）.

この結果から膵癌の組み合わせ診断は以下のよ うな方法がよいことがわかった。膵癌のスクリー ニング検査にはUSがよい. U S で大きな膵癌が 認められればCTで所見を確認する。進行した大 きな膵癌は，U S，C T で主腫瘍部とその進展様 式が確認されれば切除不能と診断してよく， E R C P や血管造影を行う必要はない. U S , C T で 
膵癌の診断がはっきりしない場合には E R C P を 行う. 2 〜次分枝までよく造影された膵管像が えられ，異常がなければ膵癌を除外榜断できる. E R C P で異常があれば血管造影を施行し，良悪 性の鑑別，墨性ならば切除可否を䛦断する.

過去 2 年間の膵癌診断の実態を上記診断過程で みると, U S 施行例 4,771 例中膵の異常を指摘した

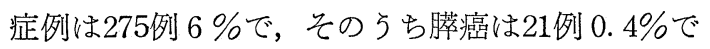
あった. U S 施行後 C Tを行ったのは 409 例で, 膵癌は15例 $4 \%$ \%゙った. US, C Tだけで切除 不能な進行猝癌と診断して, 化学療法を行った症 例は21例中 6 例 $29 \%$ であった. E R C Pは 518 例 に行い, 膵癌は11例 $2 \%$ で, 最終的に血管造影 を行ったのは255例, 膵癌は切除 3 例, 非切除 12 例, 計15例 $6 \%$ であった。

肝転移など切除不能な原因となる進展様式を考 慮にいれて膵癌21例の診断過程をみな和すと，U S，CTだけで切除不能と彮断できる症例は 15例 で, 診断能も29\%から71\%と向上し, 診断過程を 短縮できる。

\section{E. 予 後}

予後が判明した 110 例で生存曲線をみると，膵 癌患者の $50 \%$ は 3 月から 6 力月, $90 \%$ は 1 年から 1 年 6 力月の間に死亡する.

切除例, 非切除例に分けて検討すると, 切除例 の予後は明らかに非切除例のそれよりも良好であ り，5年以上生存例は 21 例中 2 例あった (表17).

腫瘍の大ささと予後の間に相関々係は認められ なかったが， $3 \mathrm{~cm}$ 以上の膵癌の $91 \%$ 切除不能で あったことから， $3 \mathrm{~cm}$ 以下の癌を診断して切除す れば予後は改善できると考觉られる。

\section{考按}

病理学的に膵癌は間質結合織の増生が著しい症 例が多く，その程度は様々である. 石舘 ${ }^{37)}$ は間質 增生の軽度なものから高度なものまで量的に I 度 からIV度に, 中村 ${ }^{38)}$ は 3 型に分類して肝転移との 関係を分析した。著者は膵癌を線維性基質量の多 いものと少ないものに大別して，血管造影所見と 対比検討した。 今回の検討では, 切除膵癌の 80
$\% ， 2 \mathrm{~cm}$ 以の小膵癌はすべて 線維性基質量は多 かった，基質量の少ない癌は大きな癌で，切除不 能な進行膵癌が多かった。

鈴木 ${ }^{48}$ は外科病理の立場から, 前方・後方, 未 よび上方・下方への浸潤は切除不能な要因である ことを指摘した。 福田 ${ }^{15)}$ は進行膵癌が門脈壁に沿 って進展する特異な形態に注目し, 病理解剖学の 立場から膵内外の進展様式を詳細に分析し，腫瘍 が大きくなれば，前方・後方浸潤共にその頻度は 増すが，基質量が多い癌では，腫瘍が小さくても 上方・下方へ進展するとのべている. とくに，鈎 部癌は全例下方浸潤例で, 特異な癌といえる.

小さな癌でも肝転移があったり，腹膜播種がみ

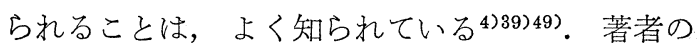
例でも， $3 \mathrm{~cm}$ 以下の癌 25 例中 8 例に膵外進展がみ られた。線維性基質量の多い進行癌の中には主腫 瘍部が縮小する例があること，鈎部・尾部の癌は 解剖学的に前後径が小さいので, 脺外に進展しや すいことがその理由と考えられる。

肝転移も切除不能な要因の1つである.肝転 移は, 線維性基質量の少ない癌に多いとする石 舘 ${ }^{37)}$, 中村 ${ }^{38)}$ の成績と一致していた.

膵癌に特異的な血管造影所見は, 動脈の encasementと閉塞である ${ }^{8331>42743) . ~ と く に, ~ e n c a s e-~}$ ment には serrated, serpiginous な $2 つ の$ 型が

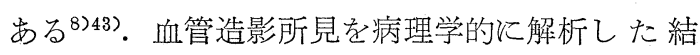
果，基質量の多い癌は辺縁が鋸歯状の狭窄，少な い癌では辺縁が直線状の狭窄が認められた。いろ いろな形の encasement は癌の線維性基質量の差 による表現の違いであり，動脈の屈曲は腫瘍が縮 小する傾向をもつ場合にみられる所見であった。 閉塞像は基質量の差に関係なく，動脈が断裂する 型が高頻度に認められた。

動脈の encasement, 閉塞は, 癌の動脈壁への 浸潤像と考号られていた ${ }^{8) 43)}$. Encasement, 閉塞 の成因を病理組織学的に研究した結果，癌が動脈 外膜を浸潤・破壊して動脈壁内に浸潤することは まれで, 動脈周囲で増生する膠原線維によって動 脈がしめつけられて生ずる動脈の変形であること が明らかになった。したがって，Moskowitz ${ }^{50)} か ゙$ 
慢性膵炎例で動脈の encasement を認めたよう に，理論上進行した慢性膵炎例に血管造影を行兄 ば，動脈の encasement，閉塞がみられることが 予測される。閉塞は encasement の終末像と考光 られるので, 動脈壁に癌浸潤が認められても当然 である.

膵癌の大ささの診断は，腫瘍が小さくなればな るほぞ血管造影が有効である. Eisenberg8) は 1 $\mathrm{cm}$, Macgregor ${ }^{9)}$ は $1.5 \mathrm{~cm}$, 有山到 $1.2 \mathrm{~cm}, \mathrm{He}-$ rlinger ${ }^{11)}$ は1. $5 \mathrm{~cm}$ の膵内に限局した小膵癌を血管 造影で確診した．組織学的に膵の動脈の異常所見 部位から癌浸潤の範囲は, encasement では膵内

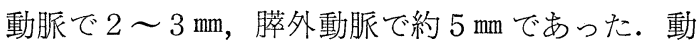
脈の閉塞がある例では膵内動脈で $2 \sim 3 \mathrm{~mm}$, 膵外 動脈で約 $10 \mathrm{~mm}$ なで癌浸潤があった。異常所見部位 を正しくプロットしていけば，肉眼的な癌の大き さが血管造影で正確に診断できる.

鈴木 ${ }^{52}$ は異常所見がある膵内動脈の数から，切 除可能性の有無を論じている. 有山搹33) は薬理学 的血管造影を行光ば門脈が十分造影され，門脈浸 潤の有無を直接的に診断でさることから，門脈浸 潤の䛦断は切除可否の決定に 重要であるとのべて いる. 閒脈系への癌浸潤は, 静脈の圧排, 狭窄, 閉 塞で正しく診断できる。血管造影で門脈が正常で も，手術時に脺癌の浸潤がみられる例がある。病 理学的に検索した結果, 膵の辺縁に位置する腫瘍 そ， $3 \mathrm{~cm}$ 以上の腫瘍は，血管造影で門脈が正常で も浸潤がある可能性が高いことがわかった。これ らの要素を組久合わせると，門脈造影所見が正常 でも癌浸潤の有無が90\%に正䛦できる。膵外動脈 に異常所見が認められる場合は， $2 \mathrm{~cm}$ 以上の腫瘍 ならば門脈浸潤があると考劣てよい。

萃被膜浸潤は，膵癌の予後を左右する因子の 1 つである ${ }^{46) 47)}$ が，その血管造影診断の報告はな い. 血管造影で動脈の変化が脺内動脈に限局して いる例で，膵外動脈に近い領域にある癌は大きさ に関係なく被膜浸潤があると予測できる.

病理学的な膵癌の検討から, 臨床的な膵癌診断 の利点と問題点を考察した.

U S は無侵襲でX線被曝がなく，肝胆膵を短時
間で検査できるので，スクリーニング検査として 最適である.リニア型電子スキャンの開発により， 膵だけでなく周辺管腔藏器の描出が簡単にできる ようになった ${ }^{18)}$. 竹原 ${ }^{199}$ は, 客観性のある膵のエ コーグラムを描出するには膵周囲の血管系を同時 に描出することが重要であり，これらの血管系の 走行が正常であるか否かにより，病変の存在とそ の進展度を知ることができるとのべている，膵癌 のU S 診断能は80〜90\%と報告されている ${ }^{16) 27229)}$ 53) 55). 切除例の報告から腫瘍の大きさの診断の 限界を調べると，2〜3 cmがその限界と報告され

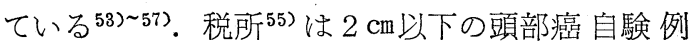
6 例の経験から，局所腫大を認めないものが多 く，所見も見逃し易い微細な所見であるとのべて いる、したがって, 肝転移など進行膵癌の進展様 式を診断すれば， $3 \mathrm{~cm}$ 以上の膵癌はU S だけで容 易に䛦断できる. 福田 ${ }^{15}$ は $2 \mathrm{~cm}$ 以下の小膵癌全例 に，主膵管の狭窄，閉塞がみられたと報告して いる. 大藤 ${ }^{18)}$ は正常膵管のU S 検出能は, 頭部32 $\%$ ，体部 $84 \% ，$ 尾部 12\% と報告している. 竹原 ${ }^{19}$ は80\%であったとのべている．膵管の直径の正常 值は, $2 \mathrm{~mm}$ 以下である ${ }^{16) 18) 199}$. 頭体部の小膵癌で 尾側膵管の拡張があれば，US で容易に診断でき るので，腫瘍が描出されなくても精密検査の手が かりがえられる. US の問題点は, 肥満者や腸 管ガスの多い例では脺の検出ができないことで ある. Arger ${ }^{53)}$ は膵の検出能は頭部77\%，体部70 \%，尾部37\%と報告しているが，著者の成績と同 様に尾部が明瞭に認められる症例が少ないことか ら，小さな尾部癌はU S では䛦断できないと考光 てよい、をた，USは artifact が多く，胃壁を拡 張した膵管と誤診したり，腸係蹚を腫瘍と見誤る ことがある57) 59).

C Tは侵襲が少なく, 客観的な人体の横断画像 がえられる。周囲脂肪織が多い例では，膵が明瞭 に描出される。C Tの膵癌診断能 は 88～96\% 20 ) 22)30) と高く, 膵の輪郭に変化が久られる大きな進 行した膵癌の診断にはもっとも有効な検査法であ

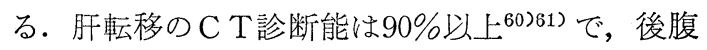
膜腔での進展, 胃・結腸, 腎臓なぞ隣接臟器への 
浸潤, 腸間膜根部への進展が高率に䛦断できる. Freeny ${ }^{30)}$ はC Tで後方進展は65例62\%，下方進展 は59例57\%に診断できたとのべている，C Tで癌 の膵外進展が明らかであれば，切除不能な膵癌と 䛦断してよい。また，C Tは膵癌に対する化学療 法, 放射線治療の效果判定にも優れている ${ }^{30}$. $\mathrm{C}$ T の問題点は，膵癌と正常膵組織の X 線吸収值 に差が少ないことである ${ }^{62)}$. 板井 ${ }^{63)}$ は膵癌切除 12 例にC Tを行い，腫瘤が診断できたのは 8 例，腫 瘤は診断できなかったが脺管・胆管の拡張を認め たのは 2 例，膵管拡張が疑われた例は 1 例，所見 なし 1 例で，膵に変形をきたさない小膵癌は診断 できなかったと報告している，著者も $2 \mathrm{~cm}$ 以下の 小膵癌 4 例は， C Tで㫃断できなかった。とく に, $1.3 \times 1.2 \mathrm{~cm}$ の尾側よりの体部癌は, 肉眼的に 尾側膵管の拡張を認めたが，C Tではこの膵管拡 張も䛦断できなかった、膵癌の疑いがある例にC Tを行っても，異常が認められない場合は膵癌を 除外できない。

E R C P は，膵癌の存在診断にもっとも有効な 検查法である. 小越64) は膵癌の膵管像を狭窄型, やせ細り型, 断裂型, 分類不能型に分類し, 分類 不能型は慢性膵炎とも膵癌とも診断できない膵管 像を呈するとしている，Bilbao ${ }^{67)}$ は本邦，欧米の 症例を検討し, 膵癌の 90\%以上に主膵管の狭窄・ 閉塞が認められたとのベている，膵癌の基本的な 膵管像は狭窄と閉塞である。Cubilla40) は508例の 非内分泌性腫瘍の病理学的研究から, 膵癌の $89 \%$ は膵管上皮から発生すると結論した.乙たがっ て，小さな腫演でも膵管の狭窄・閉塞がみられ る. 有山 ${ }^{10)}$, 高木 ${ }^{65}$, 鈴木 ${ }^{66)}$ らは自験例の経験か ら，小膵癌を診断するには E R C P は欠かせない 検査法であることを強調している，ER C P の問 題点は，手技が難しいことである。また，膵管の 狭窄・閉塞は膵癌だけでなく慢性膵炎や膵囊胞で も認められ，鑑別湸断が難しい。

Classen ${ }^{68)}$ は，膵癌と膵炎は膵管像だけからは 鑑別できないとしている. 小越 ${ }^{64)}$ は, 慢性膵炎と overlap する膵癌症例は約 10\%で，比較的早期の 癌をみつけようと努力すればそれだけ偽陽性例が
多くなり，典型例だけを診断すれば偽陰性例がで る危険があるとのべている，著者は病理組織学的 に短かい主萃管の狭窄が小膵癌, 慢性萃炎, 膵管 上皮の過形成, 主膵管壁の肥厚のいずれにもみら れることを経験した。 閉塞像も小膵癌, 慢性膵炎 で認められた、したがって，小膵癌を診断するた めには，膵管に異常があれば病変の存在を診断す るにとどめ，膵管像から確定診断すべきでない. 膵管造影像から癌の大きさ, 浸潤範囲は診断でき ない。

Herlinger ${ }^{11)}$ はU S, C Tだけで大きな膵癌は 診断できるので，血管造影の新しい役割は早期 の治癒しうる膵癌の診断であるとのべている. Stanley ${ }^{28)}$ も同様に，血管造影の役割りは切除可 否の決定にあるとしている。

Tylèn ${ }^{69)}$ は動脈の変化が膵内動脈に限局してい るか，動脈の変化がない場合は，約40\%の症例で 根治切除が可能であるとのべている. 鈴木 ${ }^{52)}$ は頭 部癌, 膨大部癌, 胆管末端部癌 87例の血管造影所 見を分析し，動脈の異常所見の数と部位から 3 群 に分類している. 1 群のうち, 前・後膵アーケー ドに変化がない例や，前膵アーケードに変化が限 局している例は根治切除ができ，長期生存が期待 できる. 前・後アーケードに限局していれば切除 可能である. $2 \cdot 3$ 群は膵外動脈に異常所見がある 症例で, 切除できても短期間の5ちに再発死亡す るか，膵外進展の著しい例であるとのべている. しかし，超選択的に膵内動脈をよく造影すれば血 管造影で癌の大きさ，その局在が正確に診断でき る.門脈系を十分に造影すれば閶脈浸潤の有無が

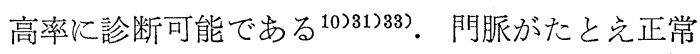
でも, 癌の大きさ・局在がわかれば閏脈浸潤も予

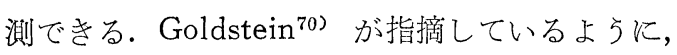
動脈の異常像だけから膵外進展の有無を診断する のは伦険である.

Rösch ${ }^{71)}$ は連続して榆查した 100 例の血管造影 䛦断能を, 正常膵 $85 \%$, 膵炎 $85 \%$, 膵䨞胞 $100 \%$, ランゲルハンス島腫瘍 $80 \%$, 膵癌 $95 \%$ と報告し, 選択的血管造影の結果と比較して, 超選択的血管 造影の重要性を強調している. 有山融は は R C P 
で脺管異常像を示した膵癌以外の疾患67例に血管 造影を行い，正診 $86 \%$ ，偽陽性11\%，誤診 1\%で， 診断が容易なのは脺賈胞，䛦断が難しいのは慢性 膵炎と結論している。このように，血管造影で膵 内動脈と閒脈をよく造影すれば，小膵癌の確定診 断，良悪性の鑑別が高頻度に可能である. また， 動脈, 門脈の異常所見から, 膵癌の進展度がくわ しく䛦断できる，血管造影の問題点はきわめて侵 襲的で，技術的に難度の高い検査法である.

\section{まとめ}

膵癌の病理学所見々血管造影所見を対比し, 各 種検査法の晾断能を比較することにより，つぎの 結論をえた。

1.膵癌の血管造影所見は, 基質量の多い癌で は動脈は屈曲・蛇行し, 鋸歯状の狭窄を呈する. 基質量の少ない癌では，動脈の狭窄の辺縁は直線 的である. 動脈の閉塞は encasement の終末像と 考光られ，直線的な断裂が多かった。

2. 血管造影で癌の大きさが晾断できる. 膵内 動脈では encasement, 閉塞から $2 \sim 3 \mathrm{~mm}$ 離れた 部位を, 膵外動脈では $5 \mathrm{~mm}$ 離れた部位をプロット した範囲が腫瘍の大ささにほぼ一致した。

3. 門脈の圧排・狭窄・閉塞は癌浸潤による変 化であることを病理学的に確認した。門脈が正常 でも膵内動脈に 2 つ上小所見があり，癌の大き さが $3 \mathrm{~cm}$ 以上であれば，閒脈浸潤がある可能性の 高いことがわかった．膵外動脈に encasement が あれば，2〜3cm の大きさの癌でも門脈浸潤があ った。

4. 動脈の encasement ・閉塞が膵内動脈飞限 局し，それらの変化が膵外動脈に近ければ，動脈 の異常所見の数, 腫瘍の大ささに関係なく被膜浸 潤があると診断できた。動脈の異常所見が膵外動 脈から離れていれば，被膜浸潤の診断はできな い.

5.U S は無侵壟で，X線被曝がないので，膵 癌診断のスクリーニング検查法として最適であ る. $3 \mathrm{~cm}$ 以上の膵癌の $91 \%$ は膵外浸潤があり， US で彮断できる. 肝転移の診断も高率に可能で
あった。 しかし， $2 \mathrm{~cm}$ 以下の膵癌や，小さな尾 部癌は䛦断できなかった。

6. C Tは, 横断面で膵癌と周团臟器・脈管と の関係を診断するのに優れていた。肝転移の診断 能も良好であった．したがって，US子併用すれ ば膵癌の診断能は向上する。しかし, U S 同様, $2 \mathrm{~cm}$ 以下の小膵癌の診断はできない。

7. E R C P は癌の大きさ, 占居部位に関係な く膵癌の存在診断ができた. U S・C Tで確䧐で きない例や，膵管拡張が認められる症例に E R C $\mathrm{P}$ 施行すれば萃癌の有無を診断できる。しか し, 膵管造影所見は非特異的であり, また, 癌の 大きさ，拡がりは猃断できない。

8. 血管造影の役割りは， US ・ C T ・ E R C $\mathrm{P}$ で確診できない病変を鑑別診断することであ る. 血管造影は膵内での癌の大きさや, 膵外進展 の有無が診断できるので; 切除可否の決定に不可 欠である.とくに， $2 \mathrm{~cm}$ 以下の小膵癌の確定䛦断 には，血管造影がもっとも有効であった。

稿を終るとのぞみ, 恩師白壁彦夫教授のご指導, ご校 閲化厚く拈礼申し上げます.また, 福田芳郎教授, 橋本 敬祐名誉教授のご指導ご䩿撻沉深謝いたします。

終始直接ご指導いただいた有山襄講師に招礼申し上 げます, また, 教室の池延東男博士, 白田一誠, 島口晴 耕各学士のご協力に感謝いたします.

\section{文献}

1）厚生の指標: 国民衛生の動向 : 23, 61 64, 1982 .

2) 梖 哲夫, 佐藤寿雄 : 膵癌の診断と治療 : 外科,

27, 1133 1143, 1965.

3 ）本庄一夫, 中瀬 明, 内田耕太郎: 日本飞拈ける 萃癌治療の現況：日癌治誌，10,82〜87, 1975.

4) 尾崎秀雄, 内藤聖二：わが国飞括ける膵癌の早期 診断の現況：日消会誌，77，1979～1983，1980.

5 ) 有山 襄, 池延東男, 炭田正孝, ほか: 膵疾患の C T 診断の位置づけ一一血管造影, E R C P , C T の 膵疾患の診断能の比較 : 臨放, 24, 1303 1309, 1979.

6 ) 有山 襄, 炭田正孝: 膵疾患の X線診断: 橋本敬 祐編, 膵の形能と機能, 131 153, 宇宙堂八木書店, 東京, 1981 .

7) Ariyama, J.: The pancreas.: Radiology in 
Disorders of the Liver, Biliary Tract and Pancreas, 118 182, Igaku-Shoin, Tokyo, New York, 1981.

8) Eisenberg, H.: Angiography of the pancreas.: In Hilal, S.K. ed., Small Vessel Angiography, 405 433, The C.V. Mosby, St. Louis, 1973.

9) Macgregor, M.C.A. \& Hawkins, F.I.: Selective pharmacodynamic angiography in the diagnosis of carcinoma of the pancreas.: S.G.O., 37, 917 921, 1973.

10) Ariyama, J. Shirakabe, H. \& Ikenobe, H., et al: The diagnosis of the small resectable pancreatic carcinoma.: Clin. Radiol., 28, 437 444, 1977.

11) Herlinger, H. \& Finley, D.B.L.: Evaluation and follow up study of pancreatic angiography.: Clin. Radiol., 29, 277〜284, 1978.

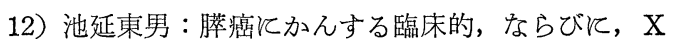
線学的研究——々く血管造影の診断的価值飞つい て：日放会誌，37，1019～1040, 1977.

13）有山 襄, 池延東男, 炭田正孝, ほか: 小膵癌の 診断過程: 胃と腸, 15，611～617, 1980 .

14）井上照信, 山田俊彦, 石 和久, ほか: 微小膵癌 の 3 剖検例：日病会誌， $65,243,1976$.

15）福田芳郎, 炭田正孝, 有山 襄, 橋本敬祐: 原発 性膵癌の病理組織学的研究——膵全割例加らみた癌 の膵内・膆外での進展様式について：胃と腸, 15, 627 635, 1980.

16) Lawson, T.L.: Sensitivity of pancreatic ultrasonography in detection of pancreatic disease.: Radiol., 128, 733 736, 1978.

17) Doust, B.D. \& Pearce, J.D.: Gray-scale ultrasonic properties of the normal and inflammed pancreas.: Radiol., 120, 653 657, 1976.

18）大藤正雄, 土屋幸治, 税所宏光, ほか: 超音波検 查, とくに電子スキャンとよる膵癌の診断 : 内科,

43, 787 794, 1979.

19）竹原靖明：超音波の画像と解剖(2)-一正常膵臟： 腹部画像䇍断, 2, 437 444, 1982.

20) Stanley, R.J. Sagel, S.S. \& Levitt, R.G.: Computed tomographic evaluation of the pancreas.: Radiol., 124, 715 722, 1977.

21) Haaga, J.R. Alfidi, R.J. \& Havrilla, T.R., et al.: Definitive role of CT scanning of the pancreas.: Radiol., 124, 723 730, 1977.

22) Sheedy, P.F.II Stephens, D.H. Hattery, R.R. \& MacCarty, R.L.: Computed tomography in the evaluation of patients with suspected carcinoma of the pancreas.: Radiol., 124, 731 737, 1977.

23）板井悠二：臨床医のためのC Tスキャン, 膵藏 :

Medicina, 18, 2169 2195, 1981.

24) Freeny, P.C. \& Ball, T.J.: Rapid diagnosis of pancreatic carcinoma. An algorithmic approach.: Radiol., 127, 627 633, 1978.

25) Kamin, P.D. Bernardino, M.E. Wallace, S. \& Jing, B-S.: Comparison of ultrasound and computed tomography in the detection of pancreatic malignancy.: Cancer, 46, 2410 2412, 1980.

26) Moss, A.A. Federle, M. \& Shapiro, H.A., et al.: The combined use of computed tomography and endoscopic retrograde cholangiopancreatography in assessment of suspected pancreatic neoplasm. A blind clinical evaluation.: Radiol., 134, 159 163, 1980.

27) Cotton, P.B. William, R.L. \& Vallon, A.G., et al.: Gray-scale ultrasonography and endoscopic pancreatography in pancreatic diagnosis.: Radiol., 134, 453 459, 1980.

28) Stanley, K.J. Sagal, S.S. \& Evens, R.G.: The impact of new imaging method on pancreatic angiography. Radiol., 136, 251 253, 1980.

29）中沢三郎，木本英三：Ultrasonography および C T 亿よる膵疾患診断: 胆と膵, 1，226～237, 1980. 30) Freeny, P.C. \& Lawson, T.L.: Adenocarcinoma of the pancreas.: Radiology of the Pancreas, 397 496, Springer-Verlag, New York, Heidelberg, Berlin, 1982.

31）有山襄, 池延東男, 黒沢 涁, ほか: 膵癌の血 管造影：胃と腸，11，1605～1617， 1976.

32) Ariyama, J. Shirakabe, H. Sumida, M. \& Bartram, C.I.: Angiographic evaluation of the abnormal endoscopic pancreatogram.: Gastrointest. Radiol., 4, 231 237, 1979.

33）有山襄, 池延東男, 炭田正孝, ほか: 選択的動 
脈造影と薬理学的動脈造影: 日本臨床, 38, 184 191, 1980.

34）有山 襄 : 膵癌の血管造影診断 : 肝胆脺, 3,745 $\sim 748,1981$.

35) Miller, J.R. Baggenstoss, A.H. Comfort, M. W.: Carcinoma of the pancreas. Effect of histological type and grade of malignancy on it's behavior.: Cancer, 4, 233 241, 1951.

36) Franz, V.K.: Tumor of the pancreas.: Atlas of Tumor Pathology, Section III, A.F.I.P., Washington DC, 1959.

37）石舘卓三 : 原発性膵癌の病理学的研究 : 秋田医誌,

4, 96 112, 1967.

38）中村宣生 : 膵癌の病理組織学的研究, 特飞癌組織 像と転移に関する知見について：千葉医会誌， 47 , 35 44, 1971.

39）井上照信 : 原発性脺癌剖検例の病理組織学的研究 並び飞腫瘍随伴性膵炎の成因について：順天堂医学, 22, 62 90, 1976 .

40) Cubilla, A.L. \& Fitzgerald, P.I.: Classification of pancreatic carcinoma (nonendocrine).: Mayo Clin. Proc., 54, 449〜458, 1979.

41）林 活次: 膵癌, A, ヒト, ヒトの癌と動物モデ ル : 癌の科学, 4, 224 257, 南江堂, 東京, 1979.

42) Lunderquist, A.: Angiography in carcinoma of the pancreas.: Acta Radiol., Supple., 235, 1965.

43) Reuter, S.R. \& Redman, H.C.: Tumors.: Gastrointestinal Angiography, 87 143, W.B. Saunders Company, Philadelphia, London, Toronto, 1972.

44）炭田正孝, 高木俊孝, 福田芳郎, ほか：膵癌の血 管造影像, 特飞 Encasement の病理組織学的検討 —in vivo, in vitro の造影所見の対比と組織連 続標本による検討：臨放，23，445～451，1978.

45）炭田正孝, 有山襄, 島口晴耕, ほか : 膵癌の血 管造影像, 特飞閉塞像の病理組織 学的 検 討—in vivo, in vitro の造影所見の対比と組織連続標本飞 よる検討 : 臨放, 25, 71〜 78, 1980.

46）佐藤寿雄, 松野正紀, 能登 陸, 斎藤洋一: 脺癌 治療に拈ける問題点, とくに進展度からみた脺癌の 予後飞ついて:手術, 31，199２08，1977.

47) 永川宅和, 米村 豊, 山口明夫, ほか : 膵癌, 膵
内胆管癌, Vater 乳頭部癌切除例の検討—とくに 進展様式と遠隔成績の相関について：日消外会誌, 14, 665 671, 1981.

48）鈴木 敞 : 膵癌の治療方針 : 外科診療, 19,545 $\sim 552,1977$.

49）石井兼央 : 膵藏の早期癌 : 胃と腸, 5, 1225 1232, 1970 .

50) Moskowitz, H. Chatt, A. \& Mellius, H.Z.: "Tumor Encasement" of the celiac axis due to chronic pancreatitis.: A.J.R., 104, 641 645, 1968.

51）有山 襄, 池延東男, 炭田正孝, 島口晴耕 : 膵癌 の血管造影：胆と脺， 1，110～115，1980.

52) Suzuki, T. Tani, T. \& Honjo, I.: Appraisal of arteriography for assessment of operability in periampullary cancer.: Ann. Surg., 182, 66 71, 1975.

53) Arger, P.H. Mulhern, L.B. \& Bonavita, J.A., et al.: An analysis of pancreatic sonography in suspected pancreatic disease.: J. Clin. Ultrasound, 7, 91 97, 1979.

54）小林正幸 : 超音波断層法による膵疾患診断に関す る研究——特飞膵の同定之䐐癌診断の臨床的研究 :

日外会誌，81，1353～1363，1980.

55）税所宏光，守田政彦，大藤正雄，ほか：膵尾部病 変飞和ける画像診断の役割一一超音波 : 腹部画像診 断, 3, 17〜26, 1983.

56) Weinstein, D.D. Wolfman, N.T. \& Weinstein, B.J.: Ultrasonic characteristics of pancreatic tumors.: Gastrointest. Radiol., 4, 245 251, 1979. 57) Goldstein, H.M. \& Katragadda, C.S.: Prone view ultrasonography for pancreatic tail neoplasma.: A.J.R., 131, 231 234, 1978.

58）須山正文, 有山 襄, 白田一誠, ほか：U Sの膵 癌診断能の評価 : 腹部画像診断, 2, 332 336, 1982.

59) Leopord, G.R.: Pancreas, Ultrasound.: In Margulis, A.R. and Burhenne, H.I. eds., Allimentary Tract Radiology, 3, 275 290, The C.V. Mosby Company, St. Louis, Toronto, London, 1979.

60) Biello, D.R. Levitt, R.G. \& Siegel, B.A., et al.: Computed tomography and radionuclide imaging 
of the liver: A comparative evaluation.: Radiol., 127, 159 163, 1978.

61) Scherer, U. Rothe, R. \& Eisenburg, J., et al.: Diagnostic accuracy of $\mathrm{CT}$ in circumscript liver disease.: A.J.R., 130, 711 714, 1978.

62) Stephens, D.H. \& Sheedy, P.F.II: Pancreas, Computed tomography.: In Margulis, A.R. and Burhenne, H.I. eds., Allimentary Tract Radiology, 3, 251 274, The C.V. Mosby Company, St. Louis, Toronto, London, 1979.

63) Itai, J. Araki, T. Tasaka, A. \& Maruyama, M.: Computed tomographic appearace of resectable pancreatic carcinoma: Radiol., 143, 719 726, 1982.

64）小越和栄: 膵癌, 内視鏡的逆行性胆道 - 脺管造影 飞招ける異常像: 竹本忠良, 春日井達造編, 膵 - 胆 道の内視鏡検査, 153 170, 医学書院, 東京, 1977.

65）高木国夫, 霞富士雄, 太田博俊, ほか: 膵癌診断 の現況一小膵癌発見のために：胃と腸， 15, 595 $\sim 610,1980$.

66) 鈴木 敞, 内田耕太郎, 戸部隆吉 : 小膵癌 $(2 \mathrm{~cm}$ 以下) 症例一一膵頭部癌 6 例の諸病像：胃と腸, 15, 641 645, 1980.

67) Bilbao, M.K. \& Katon, R.M.: Neoplasms of the pancreas. In Stewart, E.T., Vennes, J.A. \& Geenen, J.E. eds,: Atlas of Endoscopic Retrograde Cholangiopancreatography, 181 235, The C,V, Mosby Company, St. Louis, 1977.

68) Classen, M. Anacker, H. \& Stadelman, O., et al.: The diagnosis of tumors of the papilla of Vater and of the pancreas by endoscopicradiographic cholangio-pancreatography(ERCP), In Anacker, H., ed, Efficacy and Limits of Radiologic Examination of the Pancreas, 203 209, Georg Thieme Publishers Stuttgart, 1975.

69) Tylén, U. \& Arnsjö, B.: Resectability and prognosis of carcinoma of the pancreas evaluated by angiography.: Scand. J. Gastroent., 8, 691 697, 1973.

70) Goldstein, H.M. Neiman, H.L. \& Bookstein, J.J.: Angiographic evaluation of pancreatic disease. A further appraisal.: Radiol., 112, 275 $\sim 282,1974$.

71) Rösch, J. \& Holman, D.C.: Superselective arteriography of the pancreas. In Anacker, $\mathrm{H}$. ed., Efficacy and Limits of Radiological Examination of the Pancreas, 159 167, Georg Thieme Publishers Stuttgart, 1975. 


\section{Summary}

Pathological and Clinical Study of Pancreatic Carcinoma

This report compares pathological and clinical findings in pancreatic carcinoma and assesses diagnostic modalities for this condition in order to provide a data base for their rational use especially in the diagnosis of small resectable tumors.

One hundred and twenty-two patients with proven pancreatic carcinoma have been studied during the period between 1972 and 1982. Angiographic findings in pancreatic carcinoma were pathologically analyzed. The radiographic appearance of arterial encasement reflects arterial narrowing due to fibrosis from the presence of malignant cells around the vessel wall, with intimal proliferation as a secondary response producing additional narrowing and irregularity of the lumen. In arterial occlusion, the lumen is still patent, but is considerably narrowed with intimal proliferation secondary to the gross reduction in caliber of the vessel. Comparative study of macroscopic and angiographic findings revealed that angiography accurately defines tumor size. Invasion of carcinoma into the surrounding tissue can also be diagnosed with angiography. However, pancreatic capsule invasion was difficult to assess.

A prospective comparison of sensitivity, specificity and predictive value of ultrasonography (US), computed tomography (CT), endoscopic retrograde cholangiopancreatography (ERCP) and angiography was performed. ERCP had the highest sensitivity and specificity in evaluation of pancreatic carcinoma. CT was the least sensitive in detecting pancreatic malignancy. Positive predictive value was the highest in angiography, while negative predictive value was high in US and ERCP. A diagnosis of unresectable pancreatic carcinoma could be made by US and CT without need for additional imaging procedures. ERCP can show very small tumors, even when the size of the gland is normal. Angiography is a complementary examination to ERCP to determine whether the lesion is benign or malignant, and, if malignant, whether it is resectable or not.

Key words: Pancreatic carcinoma, Pathology, Angiography, Algorithmic approach.

MAsataka SUMIDA, M.D.

Department of Gastroenterology, Internal Medicine, School of Medicine, Juntendo University 